Rhode Island College

Digital Commons @ RIC

2010

\title{
British Cinema and the Manipulation of Public Opinion During the Inter-war Years
}

Merle Kenneth Peirce

Rhode Island College

Follow this and additional works at: https://digitalcommons.ric.edu/etd

Part of the Film and Media Studies Commons

\section{Recommended Citation}

Peirce, Merle Kenneth, "British Cinema and the Manipulation of Public Opinion During the Inter-war Years" (2010). Master's Theses, Dissertations, Graduate Research and Major Papers Overview. 67.

https://digitalcommons.ric.edu/etd/67

This Thesis is brought to you for free and open access by the Master's Theses, Dissertations, Graduate Research and Major Papers at Digital Commons @ RIC. It has been accepted for inclusion in Master's Theses, Dissertations, Graduate Research and Major Papers Overview by an authorized administrator of Digital Commons @ RIC. For more information, please contact digitalcommons@ric.edu. 


\section{British Cinema and the Manipulation of Public Opinion During the Inter-war Years}

Merle K. Peirce 


\section{British Cinema and the Manipulation of Public Opinion During the Inter-war Years}

Merle K. Peirce

Digital Initiatives Press: Rhode Island College

Providence

British Cinema and the Manipulation of Public Opinion During the Inter-war Years by Merle K. Peirce is licensed under a Creative Commons Attribution-NonCommercial-ShareAlike 3.0 Unported License. 



\section{Contents}

Epigraph 5

Chapter One: A Pacifist Nation 6

Table One: Casualties of World War 16

Table Two: The Peace Ballot Results 8

Chapter Two: Unilateral Disarmament 10

Chapter Three: London Films and MI-6 12

Chapter Four: Sir Alexander Korda $\quad 14$

Table Three: London Film Productions: 1933-1944 14

Chapter Five: The First Response18

Chapter Six: A More Measured Reply 22

Chapter Seven: The Hitchcockian Canon

24

Chapter Eight: The Approach to War 27

Table Four: A Chronology of Events and Film Releases

Chapter Nine: Murder, Inc. 32

Chapter Ten: After the Ball Was Over 38

Appendix A: British Prime Ministers 3339

Appendix B: Military Expenditures 1914-1946 40

Bibliography 41

Filmography 44 


\section{Epigraph}

So here I am, in the middle way, having had twenty years -

Twenty years, largely wasted, the years of entre les deux guerres

There is only the fight to recover what has been lost

And found and lost again and again:

and now under conditions

that seem unpropitious. But perhaps neither gain nor loss.

For us there is only the trying.

T.S. Eliot, East Coker, 1940 


\section{Chapter One: A Pacifist Nation}

The horrific casualties of the Great War left Britain stunned and dismayed. The reality of nearly a million deaths (estimates vary from 700,000 to 900,000 ) seemed more than the nation could handle. Although Britain had ranked third in Allied casualties, behind Russia and France, she, even more than her co-combatants was severely scarred by the number of dead, wounded, and missing. The war marked the beginning of the end of the Edwardian privileged classes and the genesis of a national democratisation and social change and disruption, culminating in the General Strike of 1926 . Her casualties had to a large extent vitiated the officer classes, and hence, the aristocracy. In peace time, many survivors were unable to work either from their injuries, or the lack of available positions; the awe with which the working class had traditionally regarded the aristocracy was gone; and commerce was severely disordered by the transition from a war footing to a peacetime economy. Britain lost a generation of capable, well educated industrial managers and civil servants, class relations were irrevocably changed, and her class fallen into a steady decline. As the decade of the twenties wore on, this malaise was transformed into very strong support for the Peace movement, which was at its strongest in Britain.

\section{Table One: Casualties of World War $1^{1}$}

\begin{tabular}{|l|l|l|l|l|}
\hline Country & Mobilized & Killed & Wounded & Total \\
\hline Australia & 330,000 & 59,000 & 152,000 & 211,000 \\
\hline Austria-Hungary & $6,500,000$ & $1,200,000$ & $3,620,000$ & $4,820,000$ \\
\hline Belgium & 207,000 & 13,000 & 44,000 & 57,000 \\
\hline Canada & 620,000 & 67,000 & 173,000 & 241,000 \\
\hline The Caribbean & 21,000 & 1,000 & 3,000 & 4,000 \\
\hline French Empire & $7,500,000$ & $1,385,000$ & $4,266,000$ & $5,651,000$ \\
\hline Germany & $11,000,000$ & $1,718,000$ & $4,234,000$ & $5,952,000$ \\
\hline Great Britain & $5,397,000$ & 703,000 & $1,663,000$ & $2,367,000$ \\
\hline Italy & $5,500,000$ & 460,000 & 947,000 & $1,407,000$ \\
\hline Japan & 800,000 & 250 & 1,000 & 1,250 \\
\hline New Zealand & 110,000 & 18,000 & 55,000 & 73,000 \\
\hline Russia & $12,000,000$ & $1,700,000$ & $4,950,000$ & $6,650,000$ \\
\hline South Africa & 149,000 & 7,000 & 12,000 & 19,000 \\
\hline Turkey & $1,600,000$ & 336,000 & 400,000 & 736,000 \\
\hline USA & $4,272,500$ & 117,000 & 204,000 & 321,000 \\
\hline
\end{tabular}

Initially, the British public was very curious about the war. The German merchant submarine Deutschland was placed on display in London with the Q-ship HMS Suffolk County, and later towed from port to port where it could be visited for ten pence. With declining interest, it was sold for scrap at the end of $1921 .{ }^{2}$ British

1 Colin Nicholson, The Longman Companion to the First World War, (New York: Pearson Longman, 2001) 248.

2 Dwight Messimer, The Merchant U-boat, (Annapolis, MD: Naval Institute Press, 19), 202-203. 
Instructional Films produced a series of filmed reconstructions of important military encounters - Armageddon (1923), Zeebrugge (1924), Mons (1926), Battles of the Coronel and Falkland Islands (1926) and Ypres (1927). These were augmented by New Era's dramatisations of The Somme (1927) and Q-Ships (1928), which exhibited a lesser documentary and more sensationalistic quality.

Public interest in this type of film seemed to be waning however, possibly as a result of the publications which Paul Doerr discusses in British Foreign Policy: 1919-1939:

In the late 1920's and early 1930's the British reading market had been flooded with a number of memoirs from first world war veterans, many of which made clear the absolute horror of war in the trenches. Edmund Blunden's Undertones of War appeared in 1928, followed by Robert Graves' Goodbye to All That in 1929 and Siegfried Sassoon's Memoirs of an Artillery Officer in 1930. Most successful by far was All Quiet on the Western Front, written by a German veteran, Erich Maria Remarque. $^{3}$

As he notes, these books contributed to the public's disenchantment with war and militarism, making rearmament a difficult programme to pursue, which Prime Minister Stanley Baldwin acknowledged in his "appalling frankness" speech of November 12, 1936:

I put before the whole House my own views with an appalling frankness. From 1933, I and my friends were all very worried about what was happening in Europe. You will remember at that time the Disarmament Conference was sitting in Geneva. You will remember at that time there was probably a stronger pacifist feeling running through the country than at any time since the War. I am speaking of 1933 and 1934. You will remember the election at Fulham in the autumn of 1933...That was the feeling of the country in 1933. My position as a leader of a great party was not altogether a comfortable one. I asked myself what chance was there...within the next year or two of that feeling being so changed that the country would give a mandate for rearmament? Supposing I had gone to the country and said that Germany was rearming and we must rearm, does anybody think that this pacific democracy would have rallied to that cry at that moment! I cannot think of anything that would have made the loss of the election from my point of view more certain... We got from the country - with a large majority - a mandate for doing a thing that no one, twelve months before, would have believed possible. $^{4}$

The peace movement found the national feelings of malaise and dissatisfaction a fertile ground for their proselytizing. Membership in peace organisations such as the League of Nations Union which numbered over a million members, and the Peace Pledge Union registered 100,000 between 1934 and 1936. Yet the movement was as Cecelia Lynch describes it was far from monolithic:

Peace movements incorporated analytically complex social and political components, motives and goals. Their ideology can be characterized as liberal in the sense of encompassing pluralistic debate over issues of militarism, international law, the content of peace, the causes of war, economic

3 Paul W. Doerr, British Foreign Policy 1919 - 1939: 'hope for the best, prepare for the worst', (Manchester: Manchester University Press, 1998) 160.

4 Keith Middlemas and John Barnes, Baldwin: A Biography (London: Weidenfeld and Nicolson, 1969), 970, 972. 
exploitation and inequalities, capitalism, and the causes of human suffering. ${ }^{5}$

The primary concerns of the movement became disarmament, promotion of the League of Nations, and changes in traditional diplomatic practice. This latter point even revealed the influence of the American branch of the peace movement in the first of President Wilson's fourteen Points -"Open covenants of peace, openly arrived at, after which there shall be no private international understandings of any kind but diplomacy shall proceed always frankly and in the public view. “6 British diplomacy therefore seemed, at least to conservative interests, to be hamstrung by the meretricious need for openness. Her Majesty's government on the other hand, made use of the movement's push for armaments reduction to defund the military and intelligence services in the face of substantial economic requirements and shortfalls.

Following the collapse of the 1932 - 1934 Geneva Disarmament Conference, the League of Nations Union promoted a National Declaration, commonly called the Peace Ballot and received a great deal of support from other groups within the peace movement, especially women and churches. The Peace Ballot's supporters included the both the Labour and the Liberal Parties, the Archbishops of York and Canterbury and more than fifty of their Bishops, the Moderator of the General Assembly of the Church of Scotland, the Catholic Archbishop of Liverpool, the President of the National Council of Evangelical Free Churches, the General Secretary of the Baptist Union, the Moderator of the English Presbyterian Church, the Chief Rabbi, film stars Sir Cedric Hardwicke, Sybil Thorndyke, Miles Malleson, Diana Wynyard, writers E. M. Delderfield, A. A. Milne and Rose Macaulay. Volunteers secured ballots from $38.2 \%$ of the British electorate. The during the poll conducted from February through June, 1935, the Peace Ballot received over 11 million votes. and its propositions were overwhelmingly approved.

\section{Table Two: The Peace Ballot Results ${ }^{7}$}

\section{Should Great Britain remain a Member of the League of Nations?}

Yes, $11,090,387$.

No, 355,883 .

Are you in favour of all-round reduction of armaments by international agreement? Yes, $10,470,489$.

5 Cecilia Lynch, Beyond Appeasement - Interpreting Interwar Peace Movements in World Politics (Ithaca: Cornell University Press, 1999), 30.

6 Henry Steele Commager and Milton Cantor, eds., Documents of American History, Vol 2, Since 1898 (Englewood Cliffs, NJ: Prentice-Hall, 1988) 134.

7 Harold Nicolson, 'British Public Opinion and Foreign Policy', The Public Opinion Quarterly, Vol. 1, No. 1. (January, 1937 ), 57-8. 
No, 862,775 .

Are you in favour of an all-round abolition of national military and naval aircraft by international agreement?

Yes, 9,533,558.

No, $1,689,786$.

Should the manufacture and sale of armaments for private profit be prohibited by international agreement?

Yes, $10,417,329$.

No, 775,415 .

Do you consider that, if a nation insists on attacking another, the other nations should combine to compel it to stop-

(a) by economic and non-military measures:

Yes, $10,027,608$.

No, 635,074 .

(b) if necessary, military measures:

Yes, 6,784,368.

No, 2,351,981.

At this time, the opinion, both of the general public and its government began to change. The expiry of the Washington Naval Treaty at the end of 1936, permitted the laying down of the five battleships of the King George V class (King George V, Anson, Prince of Wales, Duke of York, and Howe) as well as ten light cruisers of the Southampton class (Southampton, Birmingham, Glasgow, Liverpool, Belfast, Newcastle, Manchester, Gloucester, Sheffield and Edinburgh). Irrespective of the views of the peace movement, the government also initiated its Shadow Factories scheme, and sanctioned the expansion of the Royal Air Force, long campaigned for by Winston Churchill. 


\section{Chapter Two: Unilateral Disarmament}

While the peace movement's opposition to armaments of any sort would, on the surface, appear to place it in opposition to the government, His Majesty's government in fact used this opposition to limit funding of the Army, Navy, Air Corps and Intelligence services. The simple reality was that the Great War had nearly bankrupted the country, the Americans were pressing for repayment of war debts due them, and Britain's own debtors were loath to repay their loans.

The first world war heralded the end of European dominance as the true victors in the predominantly European war were America and Japan: two non-European powers. The European victors were bled white and suffered a Pyrrhic victory from which none of them ever really recovered. While this fact was not evident at the war's end, it was clear that the forthcoming settlement must far exceed in geographic scope and complexity the other periodic realignments of the power balance, the 1648 Treaty of Westphalia and the 1845 Final Act of Vienna to which it is often compared. Nobody doubted the magnitude of the task but nobody was properly prepared to undertake it. ${ }^{8}$

Following agreement with the United States in November, 1922, Britain made payments of $£ 32,800,000$ per year on its $£ 850,000,000$ debt from 1923 to 1931. During that year, American President Herbert Hoover proposed a one year moratorium on all war debt repayments. Once stopped, no agreement was ever reached on modification to the original terms, and repayments were never restarted.

The governments of Stanley Baldwin and Ramsay MacDonald, therefore kept military expenditures at an absurdly low level, hoping for no new conflict that would require them to increase funding to the armed services. As "Cato" noted in the wildly popular Guilty Men, a 1940 recrimination of inter-war politicians and policies, "The MacDonald government was pre-eminent in its practical incapacity to do anything." ${ }^{9}$ This posture was further supported and reinforced by the number of diplomatic initiatives and peace and arms reduction conferences held during 1920-1935. The result of this policy was that the country was soon entirely unprepared for war, at a time when Germany was re-equipping itself and establishing its bona fides as Britain's greatest opponent. Winston Churchill remarked on the military policy initiated for economic reasons:

It had been decided by the War Cabinet in 1919 that as part of the economy campaign the service departments should frame their estimates on the assumption that "the British Empire will not be engaged in any great war during the next ten years and that no expeditionary force will be required." In 1924, when I became chancellor of the exchequer, I asked the committee of imperial defense to review this rule; but no recommendations were made for altering it. In 1927, the War Office suggest-

8 Sally Marks, The Illusion of Peace, (London: Macmillan, 1976), 1.

9 Cato [pseud.], Guilty Men (London: Victor Gollancz, 1940), 22. 
ed that the 1919 decision should be extended for the Army only to cover ten years "from the present date." 10

A very substantial reduction of capital ships was mandated by the Washington Naval Treaty of 1922, thus the battleships, Agamemnon, Agincourt, Australia, Bellerophon, Commonwealth, Conquerer, Dreadnought, Erin, Hercules, Indomitable, Inflexible, Lion, Monarch, Neptune, New Zealand, Orion, St. Vincent, Superb and Temeraire, aggregating 383,510 tonnes were paid off and scrapped. ${ }^{11}$ By 1923, when the first war debt payment was due, military expenditures for all services had dropped to $4-3 / 8 \%$ of their 1918 levels. At no time during 1922-1936 did expenditures exceed $5 \%$ of the 1918 level.

During the twenties, Britain depended heavily upon treaty obligations and commitments to permit reductions in spending for its armed and intelligence services. Thus there were a plethora of conferences and treaties: the Spa Conference (1920); the Washington Naval Conference (1922); the Locarno Pact (1925); The Three Power Geneva Naval Conference of 1927; the General Treaty for the Renunciation of War (the Kellogg-Briand Pact) signed at Paris in 1928; the London Naval conference (1930, and 1935); the Geneva Disarmament Conference (1932-1934). John F. Kennedy summarised the situation:

...the Englishman had to be taught the need for armaments; his natural instincts were strongly against them. Internally, armaments were a menace to his economic security, as they must be paid for out of higher taxes; externally, they were a menace to his conception of a peaceful world order based on the League of Nations.

In our study of the conversion of Britain from a disarmament psychology to one of rearmament, we will see how Hitler gradually came to be considered a greater menace than larger taxes or an unbalanced budget, and how the average Englishman began to lose faith in Britain's security based on collective guarantees. ${ }^{12}$

No sooner had Hitler acceded to the German Chancellorship, then on the ninth of February, 1933, the Oxford Union debating society passed, by a vote of 275-153 the proposition "That this House will in no circumstances fight for its King and Country". ${ }^{13}$ The resolution was moved by Mr. K. H. Digby of St. john's College and opposed by Mr. K. R. F. Steel-Maitland of Balliol College. The three speakers were Mr. D. H. Graham of Balliol, with Quintin Hogg arguing against it and C. E. M. Joad arguing for it. Remembered as the "Oxford Pledge", it was adopted by the Universities of Manchester and Glasgow the following month. Britain was horrified, and the Nazis became convinced that Britain had no heart for war and would quickly fall when pressed. It now seemed, especially to the Germans, that Britain had neither the weapons to fight a war, nor the spirit to undertake one.

10 Winston Churchill,, The Gathering Storm (Boston: Houghton Mifflin, 1948), 50-51.

11 U.S. Department of State, Foreign Relations of the United States: 1922, Vol 1, (Washington, DC: GPO, 1936 ), 260.

12 John F. Kennedy, Why England Slept (New York: W. Funk, Inc., 1940), 4-5.

13 Jan Morris, ed., The Oxford Book of Oxford, (London: Oxford University Press, 1978), 374. 


\section{Chapter Three: London Films and MI-6}

When Alexander Korda settled in London, he was approached by Lieutenant Colonel Claude Edward Marjoribanks Dansey. Dansey was a man of mysterious connections, and as historian Hugh Trevor-Roper described him “..an utter shit; corrupt, incompetent, but with a certain low cunning." 14

He was also to become one of the foremost intelligence officers during the coming war. For the present, however, he began to construct a shadow intelligence network using the film industry for cover. This, he named the $\mathrm{Z}$ organisation. As the decade progressed, connections were made with other businessmen - Guy Nicholas Vansittart (Sir Robert Vansittart's youngest brother) and James Mooney of General Motors Europe, Calouste Gulbenkian, the oil magnet, Henri Deterding of Royal Dutch Shell, and a number of others, including many Germans.

Korda's connections with Colonel Dansey and his associates allowed him to establish London Film Productions in 1932, and begin building a company with which to challenge Hollywood hegemony in the commercial film arts, in somewhat the same manner that John Grierson was competing with Soviet films in the documentary sector. Dansey's friends, Solly and Jack Joel, the millionaire diamond merchants apparently provided Korda with seed money, and following the success of Private Lives of Henry VIII, Korda was introduced to Sir Connop Guthrie of Prudential Assurance which had over a million pounds each day available for investment. He used Prudential's money to start construction of Denham Studios in 1935. This was perhaps one of his worst mistakes, as J. Arthur Rank was also busy at the same time building Pinewood Studios.

...his willingness to become involved with SIS also owed much to Dansey's success, chiefly through his wide range of business contacts, in helping raise the finance for London Film Productions at a critical stage in Korda's career. It has been claimed that some of SIS's own exiguous funds were also directly invested in what proved to be a highly profitable enterprise..$^{15}$

He started by winning a small contract from Paramount (he had worked for them previously at their Joinville Studios near Paris) for a couple of "quota quickies", then began building up a stable of ensemble players. His first major project was The Private Life of Henry VIII, a film which his nephew, Michael Korda insists in Charmed Lives, was a gamble of grand proportion. In fact, however, Korda knew exactly what he was doing. Production expense was carefully calculated, to produce a film which could effectively penetrate the world,

14 Read and David Fisher, Colonel Z - The Secret Life of a Master of Spies, (New York: Viking Press, 1985$), 12$.

15 Christopher Andrew, Her Majesty's Secret Service - The Making of the British Intelligence Community. (New York: Viking Press, 1986), 358-359. 
and especially American, market. While the production cost of $£ 59,000$ was substantial, it was not excessive, and the themes of patriotism, and of combatting a foreign threat are clearly revealed and constitute a subtle hint of the involvement of the SIS. In fact, much of Korda's British work is often concerned with the glorification of the Empire, and her heroes, thus the Scarlet Pimpernel (1934), Sanders of the River(1935), Fire Over England (1937), The Drum (1938) and The Four Feathers (1939). As Roy Armes tells us in A Critical History of British Cinema:

An inordinate admiration for the antics of the upper classes is a characteristic theme...This admiration goes hand in hand with a quite uncritical vision of the glorious past...a world of story book legend peopled by romantic noblemen and great artists coloured by the patriotic endeavours of such heroes as Lord Nelson and the Scarlet Pimpernel...Korda had a total respect for royalty and through his films helped to popularise the image fostered by B.B.C. radio under John Reith. ${ }^{16}$

From 1936, many of his films also warn against future problems (Things to Come) or past threats (Dark Journey) anticipating the propagandistic The Lion Has Wings (1939) and Q-Planes. Things to Come was marked by extraordinarily prescient depictions of the London Blitz while Dark Journey featured British and German spies battling each other in neutral Sweden. These films clearly mark the interest of MI-6 and Winston Churchill. Churchill and Korda were close friends, and having seen the pleasures of fascism at close hand in 1919, Korda clearly agreed with, and supported Churchill's views on Nazi Germany and its threat to Britain. By the mid-1930's, Churchill was seeking to unite other men with similar viewpoints with a view to concerted action against the German menace.

In 1936, at the height of the Partition debate, Churchill met Eugen Spier, a German-Jewish refugee from Nazism who was living in Britain. Churchill was looking for some means to make the Nazi danger more widely known to the public, with the help of leaders in all walks of public life. Spier later recalled how 19 May 1936 'saw the first luncheon of a new group, later called the Focus, aimed at bringing together representatives of all Parties and groups opposed to Nazism.' ${ }^{17}$

1936 was a year of change, as Britain prepared to face the growing menace which Germany placed on offer. Churchill's strident voice began to be heard and, as a result, re-armament began, whilst London Film Productions and Gaumont British released a continuing series of films which endorsed patriotism and loyalty to the Empire, and revealed the threat from a foreign, often unnamed power. Gradually, even grudgingly, Britain came to accept the inevitability of war, and the need for preparation. Politically, appeasement and faith in the League of Nations were not yet dead, but their days were numbered, especially after Munich. Dansey's work with Korda and the $\mathrm{Z}$ organisation showed its value and became especially important after the Venlo incident on November 9, 1939, when MI-6's existing intelligence networks were rolled up and extinguished by Brigadier General Reinhard Heydrich's SS intelligence service - the SD.

16 (Roy Armes, A Critical History of British Cinema (New York: Oxford University Press, 1976), 123-124.

17 Martin Gilbert, Churchill and the Jews (New York: Henry Holt, 2007), 135. 


\section{Chapter Four: Sir Alexander Korda}

Alexander Korda was, and remains, one of the most interesting figures within the British film industry. Born in Hungary in 1893, he began directing as early as 1914, and served Béla Kun's Communist government by heading up the Film Directorate. Serving with him on the Directorate was Michael Curtiz. The actors' union was headed by Bela Lugosi. In August, 1919, units of the Romanian Army invaded and overthrew Kun's Soviet republic. During the "White Terror" that followed, thousands were executed and their bodies cast into the Danube, which became clogged with corpses rotting and festering in the heat. As the Romanians withdrew, Admiral Miklos Horthy and right-wing Hungarian conservative groups came to power. Korda himself was condemned to death, and was only rescued through the intervention of Brigadier Frederick (?) Maurice, a British intelligence agent. Leaving Hungary in the fall of 1919, he worked as a director in Germany, Austria and France, never to return to Hungary. From 1927 to 1931, he worked in Hollywood, before relocating to Britain.

In Britain, he launched London Film Productions with the quiet assistance and support of bothColonel Claude Dansey and the Special Intelligence Service, and Robert Vansitart of the Foreign Office. With their secret funding and support, he was able to build the only British film studio to successfully compete in the international market, producing films equal in quality and appeal to those made by Hollywood itself.

Table Three: London Film Productions: 1933-1944 ${ }^{18}$

\begin{tabular}{|l|l|l|c|}
\hline Year & Title & Director(s) & Length \\
\hline 1933 & $\begin{array}{l}\text { The Private Life of Henry the } \\
\text { VIII }\end{array}$ & Alexander Korda & 97 \\
\hline 1933 & The Girl from Maxim's & Alexander Korda & 79 \\
\hline 1934 & The Rise of Catherine the Great & Paul Czinner & 95 \\
\hline 1934 & The Private Life of Don Juan & Alexander Korda & 89 \\
\hline 1934 & The Scarlet Pimpernel & Harold Young & 97 \\
\hline 1935 & Sanders of the River & Zoltan Korda & 98 \\
\hline 1935 & Moscow Nights & Anthony Asquith & 100 \\
\hline 1935 & The Ghost Goes West & René Clair & 95 \\
\hline 1936 & Things to Come & William Cameron Menzies & 117 \\
\hline 1936 & Rembrandt & Alexander Korda & 85 \\
\hline 1936 & Men Are not Gods & Walter Reisch & 90 \\
\hline 1936 & The Man Who Could Work & Lothar Mendes & 82 \\
\hline 1936 & Miracles & & 73 \\
\hline
\end{tabular}

18 table from imdb 


\begin{tabular}{|c|c|c|c|}
\hline 1936 & Conquest of the Air & $\begin{array}{l}\text { Zoltan Korda } \\
\text { Alexander Esway } \\
\text { John Monk Saunders } \\
\text { Alexander Shaw } \\
\text { Donald Taylor }\end{array}$ & 71 \\
\hline 1937 & Farewell Again & Tim Whelan & 85 \\
\hline 1937 & Knight Without Armour & Jacques Feyder & 107 \\
\hline 1937 & Action for Slander & Tim Whelan & 83 \\
\hline 1937 & Return of the Scarlet Pimpernel & Hans Schwartz & 92 \\
\hline 1937 & Paradise for Two & Thornton Freeland & 77 \\
\hline 1937 & The Squeaker & William K. Howard & 77 \\
\hline 1937 & Elephant Boy & $\begin{array}{l}\text { Zoltan Korda } \\
\text { Robert J. Flaherty }\end{array}$ & 80 \\
\hline 1937 & Storm in a Teacup & $\begin{array}{l}\text { Victor Saville } \\
\text { Ian Dalrymple }\end{array}$ & 87 \\
\hline 1937 & Fire Over England & William K. Howard & 92 \\
\hline 1937 & A Romance in Flanders & Maurice Elvey & 62 \\
\hline 1937 & I, Claudius & Josef von Sternberg & - \\
\hline 1938 & South Riding & Victor Saville & 85 \\
\hline 1938 & The Drum & Zoltan Korda & 104 \\
\hline 1938 & Prison Without Bars & Brian Desmond Hurst & 72 \\
\hline 1938 & The Challenge & $\begin{array}{l}\text { Milton Rosmer } \\
\text { Luis Trenker } \\
\text { Vincent Korda }\end{array}$ & 76 \\
\hline 1938 & The Divorce of Lady $X$ & Tim Whelan & 92 \\
\hline 1939 & The Four Feathers & Zoltan Korda & 129 \\
\hline 1939 & Over the Moon & Thornton Freeland & 85 \\
\hline 1939 & The Lion Has Wings & $\begin{array}{l}\text { Adrian Brunel } \\
\text { Brian Desmond Hurst } \\
\text { Michael Powell } \\
\text { Alexander Korda }\end{array}$ & 76 \\
\hline 1940 & 21 Days & Basil Dean & 72 \\
\hline
\end{tabular}




\begin{tabular}{|l|l|l|c|}
\hline 1940 & The Thief of Bagdad & Ludwig Berger & 106 \\
& Tim Whelan & \\
& Michael Powell & \\
& Zoltan Korda (uncredited) \\
& Alexander Korda (uncredited) \\
& $\begin{array}{l}\text { William Cameron Menzies } \\
\text { (uncredited) }\end{array}$ & \\
\hline 1941 & That Hamilton Woman & Alexander Korda & 128 \\
\hline
\end{tabular}

The success of The Private Life of Henry the VIII was immediate, lucrative and gratifying. This film built and confirmed Korda's reputation and opened the door for greater investment. By 1935, he was building the largest and most modern studios in Britain - Denham.

Korda commissioned his longtime friend, Winston Churchill to write scripts for him. Although the films were never produced, they gave Churchill an income during some of his bleakest times. As Korda was building Denham, Churchill was building the Anti-Nazi League and preparing for a return to office. All the while Dansey expanded his intelligence network, adding new operatives and preparing for the coming war. Korda collaborated with screenwriter Lajos Birò, and his brothers Zoltan and Vincent to produce a quartet of imperialist films: Sanders of the River (1935), Elephant Boy (1937), The Drum (1938), and The Four Feathers (1939).

These Empire films represent the highest and strongest expression of Alexander Korda's political sympathies. These films are commonly based on reworked novels by A.E.W. Mason (The Four Feathers and The Drum), Rudyard Kipling (Elephant Boy) or Edgar Wallace (Sanders of the River). Korda's friend, Hungarian novelist Lajos Biró assisted with the screenplays for all except Elephant Boy. Sanders of the River extols the virtues of the resident commissioners of the 1930's, and is set in Nigeria. As the film announces in its opening titles,

Africa...

Tens of millions of natives under British rule, each tribe with its own chieftain, governed and protected by a handful of white men whose everyday work is an unsung saga of courage and efficiency.

This unsympathetic, patronising attitude toward the native populations, which appears in all of the imperial films, led star Paul Robeson (Bosambo) to severely criticise and disown the film. Director Zoltan Korda was 
also reported to be unhappy with the racist, imperialist slant which emerged in the final version of the film.

Elephant Boy and The Drum used the India of the Raj as their setting. Elephant Boy was intended to bring Kipling's Toomai of the Elephants to the screen. Famed documentarian Robert Flaherty with cinematographer Osmond Borradaile shot reels of film of elephants and also discovered Sabu, a young boy who was raised to international stardom by Elephant boy and a number of succeeding films. Over the course of a year, Flaherty shot 300,000 feet off $\mathrm{ilm}$, and overspent the $£ 30,000$ budget by $£ 60,000$. Most of the footage was never used. The Drum returns to the more military subject matter, which Korda favoured. Natives plot to overthrow the British, killing one of their allies and spreading rebellion on the Northwest Frontier. The film tends to demonstrate the inherent intransigence and untrustworthiness of inferior peoples.

The Four Feathers is considered his brother Zoltan's finest work. It is a wonderful technicolour product based on General Herbert Kitchener's assault on Abdullah al-Taashi's forces at Omdurman in the Sudan in during September, 1898. It has all of the extravagance and panoply of imperialism that satured Hollywood's own productions. The Lajos Biró/R. C. Sherriff/Arthur Wimperis script is well done both it and the film are significantly better than Korda's earlier Sanders of the River and is marked by the superior cinematography of Georges Périnal and Osmond Borradile. Using music composed by Miklos Rosza, one of the great composers for film, it stars Ralph Richardson, and C. Aubrey Smith, both excellent and well established actors. Smith was brought over from America especially for this, perhaps the best of the Korda imperial films. The Empire films, however, are but a part of the body of politicised features which London Films produced, comprising perhaps as much as $50 \%$ of the studio's total output.

Following the Aldgate Trust Scandal in 1937, Korda returned control of Denham studios over to Prudential Assurance. Shed of the great financial burden which the Denham and the Prudential loans imposed, he sought other venues for his operations. Korda never forgot his debt to MI-6, and worked with producer Irving Asher (Irving Asher Productions) to make a trio of espionage films, Q-Planes, The Spy in Black, the first joint work from Michael Powell and Emeric Pressburger, and Ten Days in Paris. Under the London Film Productions banner, he made the War's first propaganda film, The Lion Has Wings (1939), designed to prepare the viewer for a sea change in attitude and point of view. Korda was especially helpful during the period between Britain's declaration of war with Germany in 1939, and The United States' own declaration in 1941. As war became reality, Churchill asked Korda to provide cover for British Security Coordination, which he did, opening and expanding offices in both New York and Los Angeles. He resettled his brothers Zoltan and Vincent in Hollywood, found suitable quarters for himself and his wife Merle Oberon, and transferred most of his production there. He shuttled back and forth between London, New York and Hollywood, often flying in unheated mili- 
tary aircraft. He provided cover for the intelligence services at a time when the United states was ostensibly neutral, and while being scrutinised by a number of conservative, even pro-Nazi congressmen. His production of That Hamilton Woman placed him in jeopardy as a British propagandist violating American neutrality laws, but fortuitously, the Japanese bomber Pearl Harbor only days before he was to appear before a committee of congressional inquiry, rendering their concerns quite moot. As his nephew Michael Korda notes in his memoir Charmed Lives,

While there has always been considerable speculation as to the exact nature of the services Alex was being rewarded for, the fact was that Churchill himself was determined to compensate Alex for the criticism he had received. At Churchill's request, he had gone to America and made That Hamilton Woman with his own money and every penny he could borrow; on Churchill's orders had had established large offices in New York and Los Angeles (far larger than he needed) to act as clearing houses for British intelligence, and by reissuing his films in the United States he was earning substantial sums for the British Treasury, which desperately needed dollars to finance arms purchases. ${ }^{19}$

\section{Chapter Five: The First Response}

On the morning of the thirtieth of January, 1933, Adolf Hitler became Chancellor of the German Republic in a simple swearing-in ceremony. On the twenty-seventh of February, the Reichstag building burned and on the following day President von Hindenburg signed the Reichstag Fire Decree. On March twenty-third, the Reichstag passed the Enabling Act, 441-94. Hitler was now in full control of the German state. By September 29, Jews were banned from all cultural and entertainment activities (literature, art, film and theatre).

Apart from regulating the financing of films, one of the main purposes of the establishing of the Reichsfilmkamer was the removal of Jews and other entartete künstler (degenerate artists) from German cultural life, since only racial 'pure' could become members. Whoever wished to participate in any aspect of film production was forced to become a member of the RFK. Goebbels, however, was given the power to issue exemptions to these conditions. ${ }^{20}$

Jewish artists and technicians realised that more trouble lay ahead and began an exodus out of the country - to Paris, London or Hollywood. Performers Elisabeth Bergner, Peter Lorre, and Richard Tauber; directors Lothar Mendes and Bernard Viertel; designers Alfred Jung and Oscar Werndoff; producers Paul Czinner and Erich Pommer all abandoned Germany for Britain. Many coming to England were welcomed by the Ostrer family which owned Gaumont-British and Gainsborough Pictures, or Alex Korda's London Film Productions. The Ostrer brothers (Isidore, Maurice and Mark) were Jewish merchant bankers who gained control Gaumont-British

19 Michael Korda, Charmed Lives - A Family Romance (New York: Random House, 1979), 155.

20 Welch 11 
in 1927 in a series of combinations which combined film distribution, exhibition theatres and film production facilities into one very substantial corporation with $£ 4,000,000$ capital.

For London Film Productions, The Private Life of Henry VIII, begun in May, 1933 was the first film to exhibit the characteristic values of British patriotism. Clearly exhibiting the interests of the intelligence services, it presented a scene where Henry's fulminations both critique the Baldwin government and endorse Churchill's position on rearmament:

King Henry VIII: Diplomacy? Diplomacy, my foot! I'm an Englishman - I cant say one thing and mean another. What I can do is to build ships, ships, and then more ships!

Thomas Cromwell: You mean, double the fleet?

King Henry VIII: Treble it! Fortify Dover! Rule the sea!

Thomas Cromwell: To do this will cost us money, sire.

King Henry VIII: To leave it undone will cost us England! ${ }^{21} \mathrm{http}: / / w w w . i m d b . c o m / t i t l e / t t 0024473 / q u o t e s$

Actor Conrad Veidt, famous for his rôle as Cesare in Das Kabinett des Doktor Caligari (1919), was a fervent anti-Nazi. Married to a Jewish woman, he fled Germany when Hitler came to power. He became one of Britain's most popular artists. He starred in The Wandering Jew, made at Julius Hagen's Twickenham Studios. It was distributed by Gaumont, and was at least partially financed by them also. Based on a medieval legend, the film portrayed a man cursed by Christ for his selfishness, one who over time learns his errors and attains spiritual growth. Veidt's own talent and abilities overcame a weak script. As Jeffrey Richards notes in The Unknown 1930's,

He slows the pace of his delivery, modulating his voice so that the lower registers are more audible. The body language augments the sense of stateliness and power; it is deliberate, and the movements are flowing and integrated. The facial expressions are lingering, and shown to best advantage by some extremely sympathetic camera work and lighting. The overall impression of the Jew is of an individual stoically suffering the pains of immortality, attaining enlightenment and transfiguration. ${ }^{22}$

Gaumont-British contracted with Veidt to star in Jew Süss, another of their early films designed to influence public opinion. It was one of their first major productions, budgeted at over $£ 100,000$. A personal project very dear to Michael Balcon, it was also endorsed by Isidore Ostrer, and carried the support of his brother Mark Ostrer, most visibly demonstrated when they visited the United States to promote the film. Mark Ostrer booked the film for a premiere at Radio City Music Hall. Leon Feuchtwangler's novel Jud Süss was original21 Ibid., 128.

22 Jeffrey Richards, The Unknown 1930's (New York: I. B. Tauris, 2000), 44. 
ly about a powerful ghetto businessman who believes himself to be a Jew. Suss' ruthless business practices result in the betrayal of an innocent girl, for which he is arrested and sentenced to be hanged under the anti-Jewish laws of the 18th century. While he waits to be executed, Süss discovers he is not Jewish. Rather than turn his back on the people of the ghetto with whom he had grown up, Süss courageously refuses to declare his "Aryan" status, even though it means he will die on the gallows. The Feuchtwangler's book was designed in roundabout fashion to strike a blow against anti-Semitism.

In his autobiography Michael Balcon Presents...A Lifetime of Films Balcon describes the appalling difficulty they experienced with the German government's sequestration of their star player:

A more important consequence of I Was a Spy was our decision to offer a term contract to Conrad Veidt. He had recently married a most charming Jewish woman, Lily, and apart from the opportunity of working in London, he obviously felt that his wife would be happier outside Germany, with its growing anti-Semitism. Before he started work on his first film under the the new contract, Connie was committed to making a film in Germany, so he returned there, leaving Lily in England; they had taken a house in Hampstead. We had announced that he was to play the title role in Jew Süss. Lily was by this time a close friend of my wife and myself and we were all much concerned over guarded implications in Connie's letters that all was not well.

He did not report in London on the contract date, which was some time in advance of the production date, and there followed a curiously formal letter from him, enclosing a doctor's certificate that he was not well enough to work. After more correspondence we were convinced that pressure was being brought to bear on him not to play in Jew Süss, a work which was anathema to the German government not only for its subject matter, but because the author, Leon Feuchtwanger, was one of the early German Jews to express his contempt for the Nazi regime.

I consulted my lawyer and he suggested the name of a distinguished London doctor, whom he knew well, who was willing to travel to Germany and examine Conrad Veidt. After a great deal of difficulty this was arranged. The doctor declared that Conrad Veidt was fit to work and the German authorities, apparently unwilling to create a minor incident allowed him to travel to England. Our suspicions were immediately conformed by him, and he was never to return to Germany again. ${ }^{23}$

To these three major films can be added Whither Germany? directed by J. B. Williams. Cited by Rachel Low as "the first film maker to draw attention to the threat to peace involved in Hitler's rise to power" ${ }^{4}$ his film ran only 37 minutes, relying heavily on newsreel footage and archival film. The British Board of Film Censors refused to give it a certificate, but its showing was permitted by several local authorities. Basil Dean's Loyalties which dealt with anti-Semitism in society was approved with only minor changes. Its chief character, Ferdinand de Levis is made up to look like Hitler.

One distinct problem for film makers during the the 1930's was the attitude of the British Board of Film Censors. Claiming that Germany was a friendly ally, it refused to approve any film critical of Germany, or, indeed, 23 Balcon 75-76.

24 Rachel Low, Films of Comment and Persusion of the 1930's, (London: George Allen and Unwin), 73. 
Italy or Japan, or any films which dealt with contemporary anti-Jewish prejudice and abuse.

In The Hidden Cinema - British Film Censorship in Action 1913-1975, James Robertson clarifies some of the reasoning behind these extremely reactionary positions of the board:

Censorship for adults is, in whatever guise, always at rock bottom a device to perpetuate the political and social status quo, and it is surely no accident that as soon as a communication medium has threatened to extend ideas and awareness to the lower stratum of British society, governments and parliament have taken measures to safeguard their decision-making hegemony between general elections. ${ }^{25}$

Although newsreels were supposed to be exempt from BBFC approval, all of the major newsreel produc-

ers (British Pathé, British Movietone, The March of Time, Gaumont British, British Paramount, Universal Talking

News, Topical Budget, Empire News, etc.) avoided reporting anti-Jewish undertakings in Germany.

If anti-Semitism occupied pride of place in implicit film attempts to warn against Nazism before 1935, the international dangers from a revived Germany under Hitler's thumb were by no means neglected. In this respect the film companies preferred to tackle the BBFC by stealth rather than head-on clashes. ${ }^{26}$

Rachel Low, writing in Film Making in 1930's Britain, well characterised the prevailing attitudes of the BBFC

with which the production companies had to deal, and it is worth reviewing her comments:

Perhaps more harmful than prudishness and religious taboos were the politics of members of the Board and their diligence in detecting subversion. They never questioned the social and political assumptions of the extreme right wing, which apparently seemed to them normal, neutral, desirable and non-controversial. In this they certainly did not reflect public opinion for although the Conservatives won the 1935 election, Labour had 8,235,491 votes to their 10,496,300, or nearly 45 per cent of their combined total, and their was in addition a strong Liberal Party. The prohibition of any serious treatment of social or political questions, the extraordinary lengths to which they would go to protect established authority of any sort not merely from attack but from disrespect, assumed that the status quo was perfect. Their attitudes to the Soviet films and the two anti-Nazi films are significant, with their acceptance that films from a socialist country were highly dangerous and that Nazi Germany was a friend of Britain. With an unofficial censorship so devoted to authority in all its forms, there was little need for government participation, and throughout the decade the Home Secretaries gave the same dusty answer to concerned MPs and pressure groups. Film censorship was not their business. But, deplorable as the negative and reactionary influence of the Board was, an official censor pursuing an active political policy might well have been worse. ${ }^{27}$

As 1933 faded into 1934 both Germany and Japan had resigned from the League of Nations, and Gaumont, especially, adopted a subtler approach to the political and social questions which vexed both world Jewry and Winston Churchill.

25 Robertson 94-95, 158

26 I.

27 Rachel Low, Filmaking in 1930's Britain, (London: George Allen and Unwin, 1985), 71-72. 


\section{Chapter Six: A More Measured Reply}

The situation at Gaumont British, whilst encompassing and effected by many of the same influences as London Film Productions', developed in a somewhat different and independent manner. Gaumont's efforts formed a much smaller percentage of total production than that of London Film. Gaumont produced a substantially larger catalogue of titles, reflecting its place as the largest of the inter war film producers. Its connexions to government were of a greater subtlety which also characterised its propagandistic undertakings, especially after 1934 .

But Gaumont-British, the biggest film company and the one for which Balcon worked, was so close to the government - and, indeed, in 1935 Isidore Ostrer, the company's chairman, made a secret agreement with the government to place his entire organization at its disposal. The fact that the scripts of the Gaumont British Imperial epics were all vetted and passed by the BBFC, and that the Korda epics were produced with the full coöperation of the Army and the colonial authorities in India, Nigeria and the Sudan, confirms that the government was happy with the Imperial image that was being projected. ${ }^{28}$

Film was accepted as a medium for effecting change in opinion by the British government, taking perhaps a back seat only to Germany and the Soviet Union in the appreciation of its power and potentialities. As John Grierson wrote in Sight and Sound (Winter 1933-34):

I look on cinema as a pulpit, and use it as a propagandist; and this I put unashamedly because, in the still unshaven philosophies of cinema, broad distinctions are necessary. Art is one matter, and the wise, as I suggest, had better seek it where there is elbow room for its creation; entertainment is another matter; education, in so far as it concerns the classroom pedagogue, another. Propaganda another; and cinema is to be conceived as a medium, like writing capable of many forms and functions. A professional propagandist may well be especially interested in it. It gives generous access to the public. It is capable of direct description, simple analysis, and commanding conclusion, and may, by its tempo'd and imagistic powers, be made easily persuasive. It lends itself to rhetoric, for no form of description can add nobility to a simple observation so readily as a camera set low, or a sequence cut to a time-beat. But principally, there is this thought that a single say-so can be repeated a thousand times a night to a million eyes, and, if it is good enough to live, to millions of eyes. That seven-leagued fact opens a new perspective, a new hope, to public persuasion. ${ }^{29}$

Grierson was heavily influenced by Russian directors and theorists, especially Eisenstein and Pudovkin. As he relates, in his work at the Empire Marketing board, the film unit viewed documentaries from all over the world, especially the work of the Russians, and its film unit became a unique type of film school, analogous to the VGIK in Moscow. Following the declaration of war, most documentary film units were converted to the production of war propaganda, with surprising speed.

The Ostrer brothers, like Alexander Korda, appreciated the dangers of Fascism and Anti-semitism. While Korda had experienced this at first hand in 1919, the Ostrers' father, Nathan, had fled Russia to escape the Jewish persecutions of the 1870's there. Both hired refugees from the German film industry in the wake of the Nazi takeover, and both were patriotic supporters of an Imperial Britain.

Michael Balcon, Gaumont's chief of production from 1931-1936, even produced an Imperial trilogy, comparable to Korda's own imperial trilogy (or quadrilogy, depending upon the critic), consisting of Rhodes of Africa (1936), The Great Barrier (1936) and King Solomon's Mines (1937). Beyond these, there is even a "lost"' epic, Geoffrey Barkas' Soldiers Three (1936) which was never completed. Jeffrey Richards has commented that the Balcon films portrayed an earlier period than that which Korda favoured for his films. Rhodes of Africa and King Solomon's Mines, as well as The Great Barrier are set approximately fifteen years before the time of Korda's films.

28 bchp250

29 Grierson, 156 
Both Balcon and Hitchcock were close friends of Korda, so they would have been familiar with both his projects and his intentions. Although he might not have favoured them with the details of his relations with MI-6, he would have had no problem talking with them about his support for Churchill's warnings of danger from Nazi Germany and the need to rearm. These were, after all, widely reported in the press, especially in his friend Lord Beaverbrook's Daily Express. These also would have resonated with Balcon's Imperial sagas, and with the small number of ant-German films, based on World War I historical confrontations, as I was a Spy (1934) and Brown on Resolution (1935). These resemble closely and anticipate the later Korda films Dark Journey (1936) and The Spy in Black (1939). Balcon's work at Gaumont British encountered only one serious obstacle, the hateful obstructionism of C. M. Woolf, who detested Hitchcock's work and with Balcon absent in America on business in 1935, tried to destroy The Man Who Knew Too Much, even to the point of offering it as a second feature when distributed and proposing to reshoot it with another director. Even with second billing, the film was immesnsely popular, and Woolf was forced to concede the battle, never to attempt such behaviours again. The films of Alfred Hitchcock created the greatest interest, however, and constituted a series of espionage thrillers and extended character studies which established a level of efficacy and artistic merit challenged only by Leni Riefenstahl's Triumph des Willens (1934) and Olympia (1936). 


\section{Chapter Seven: The Hitchcockian Canon}

Hitchcock was Balcon's special protégé. It was he who had first hired him as art director, and who had given him his first opportunities to direct, and later to direct his first complete film at Gainsborough Films. Hitchcock had jumped to British international Pictures in 1927, but Balcon persuaded him to join Gaumont British in 1933.

Balcon and Hitchcock followed Alexander Korda in working to promulgate Winston Churchill's warnings on the danger of Germany and the need to rearm. The British film industry and national intelligence organisations played an important rôle in that process, with special consideration and application of the theories and practice of John Grierson, founder of the British Documentary Movement. Early sound films Journey's End (James Whale, 1930) and Tell England (Anthony Asquith,1931) were anti-war films playing to the national distaste for combat. In opposition to these were a pair of Gaumont-British films (The Jew Süss, The Wandering Jew) trying to establish the equality and humanity of Jewry, and by Korda films such as The Private Life of Henry VIII, which began the process of extolling Britain's imperial heritage.

The finest and most successful of Gaumont's efforts were the exciting and sophisticated quintet of espionage films directed by Alfred Hitchcock. As Maurice Yacowar remarks in his discussion of early Hitchcock, Hitchcock's British Films,

In the five years, 1934-38, Hitchcock was to produce the six films which established the essentials of the "Hitchcock touch" and which came to be considered the Golden Age of Hitchcock's British period. ${ }^{30}$

Starting in 1935, and appearing nearly every year until 1939, these films warned, in somewhat vague terms, of a foreign power whose purpose was the destruction of Britain. As Anglo-German relations deteriorated, the implication that that foreign nation was Germany, became stronger, until in The Lady Vanishes, it is unmistakably clear that Vandrika is the Reich itself. Beginning with The Man Who Knew Too Much, and continuing through Sabotage and Secret Agent, Hitchcock hones his directing skill and style, establishing an approach that permeated all of his later films. These four films establish a level of subtlety and sophistication which far outstrips other films of the period. Indeed, their delicacy and depth, comprising multiple layers of meaning mark them as intelligent and artistic vehicles for bearing their propagandistic message. In point of fact, the propagandistic nature of these films is often overlooked. While he used the espionage theme less and less frequently after the war films of 1940-1945, he did make exceptions with

30 Maurice Yacowar, Hitchcock's British Films, (Hamden, Connecticut: Archon, 1977), 167. 
North by Northwest (1959) and the Cold War films Torn Curtain (1966) and Topaz (1969). As Sam Simone concludes in Hitchcock As Activist -Politics and the War Films,

Hitchcock's democratic ideology is historically recorded. Foreign Correspondent, Saboteur, Lifeboat and Notorious, which are film documents of world politics and history. The continuous political spine of suspense in these films is whether freedom, sponsored by democracy, will prevail in the United States and the world. Although Hitchcock, as activist, experienced the anxiety of America's vicissitudes of isolationism and ideological conflict during the World War II era, he never lost faith in this country's democratic objective to help purge the world of Nazi tyranny through supporting the war effort and post war internationalism to reestablish and maintain world peace and freedom. ${ }^{31}$

Yet Hitchcock was doing nothing in 1940-1945 that he had not previously done in 1934-1939. He continued to warn of the German danger. By 1940, Britain was fully involved in rearming, his brief from Britain was simply to make films favourable to his native country. Hitchcock did not even become an American citizen until 1955. Rather than concentrating on supporting American democracy, Hitchcock's prime purpose was unmasking Nazi tyranny and facilitating its defeat.

The structure of the Hitchcock film often derives from the espionage quartet of the 1930's, which themselves were an elaboration of his exploratory work with the railway thriller genre in Number Seventeen (1931). Hitchcock's espionage scripts at Gaumont were written by Charles Bennett, often assisted by the Scottish novelist Ian Hay. In the case of The Man Who Knew Too Much, Bennett worked with D. B. Wyndham-Lewis, biographer and newspaper humourist. For this film, the title reflected a collection of short shories by G. K. Chesterton, but much of the work originated with Bennett and Wyndham Lewis, and evolved from an incident which transpired when Winston Churchill was Home Secretary: the 1911 Sydney Street Siege, or "Battle of Stepney." This suggests, perhaps, Alexander Korda's influence. Hitchcock's other films were also derived from published fiction. The 39 Steps was by John Buchan; Secret Agent was based on a pair of Somerset Maugham's Ashenden short stories, "The Traitor” and “The Hairless Mexican” while Sabotage was derived from Joseph Conrad's The Secret Agent. A major exception to this line of development was The Lady Vanishes, in which Ethel Lina White's novel The Wheel Turns was given a screen treatment by the legendary team of Sidney Gilliatt and Frank Launder. Hitchcock was brought in rather later in the pre-production phase. Yet a Launder and Gilliatt (later to form the production company of The Archers) script cannot be faulted, and even though the film was reported to be already cast, Hitchcock had used Donat before in The 39 Steps and Michael Redgrave in Secret Agent. Of the main stars, only Paul Lukas, Googie Withers and Dame May Whitty had not previously worked with Hitchcock, and all had well established reputations. The comedic duo of Naunton Wayne and Basil Radford were the hit of the film, and their roles as Charters and Caldicott were reprised several times, beginning with Night Train to Munich (1940), sometimes thought of as a sequel to The Lady Vanishes.

31 Sam P. Simone, Hitchcock As Activist - Politics and the War Films, Ann Arbor: UMI Research Press, 1985), 169. 
To Hitchcock's work may also be added Bernhard Viertel's The Passing of the Third Floor Back (1934). Often overlooked, or purposefully ignored, this film provides an opening for Hitchcock's series, even though it has no direct relationship to Germany or espionage. Based on a play by Jerome K. Jerome (remembered chiefly for his Victorian humour piece Three Men in a Boat - To Say Nothing of the Dog, 1889) it was scripted by Michael Hogan, and Alma Reville - Hitchcock's wife. Starring Conrad Viedt as an angelic character, and Frank Cellier as his opposite, satanic opponent, and the charismatic Mary Clare as the landlady, it casts the struggle between good and evil in the most commonplace of institutions: the boarding house. Veidt remarked that he felt it his most challenging rôle. Despite its ungainly name, The Passing of the Third Floor Back presented an introduction to the political playing field of the time, and made clearer perhaps, the dilemma which Hitchcock took up with such skill. These six films, along with Jew Süss, constitute the core of the Balcon-Hitchcock programme of influence. Other considerations, such as the Ostrers' attempt to penetrate the American and World markets dictated that the bulk of its production be focused on entertainment films, vehicles for the singing and comedy of Jessie Matthews, Will Hay, and Tom Walls. 


\section{Chapter Eight: The Approach to War}

Not all British studios followed the lead of Britain's two major companies, London Film Productions, and Gaumont-British, in advocating rearmament, and warning of Hitler's German threat. British International, (combined with Associated British Pictures from 1937), even made a few films opposing war or rearmament, notably Norman Lee's Forgotten Men: War As It Was (1934) and Walter Summer's The Return of Bulldog Drummond (1934). This attitude did not hold for long, however, and by 1937, Bulldog, in Bulldog Drummond at Bay, was fighting foreign spies, while in 1940, Lee directed Mein Kampf, My Crimes a conventional propaganda piece which catalogued Hitler's history.

Julius Hagen's Twickenham Studios, which had made The Wandering Jew for Gaumont-British in 1934, made no more politically charged films. Trying to capture a share in the international markets, Hagen was very nearly successful, but distribution was an insurmountable problem, as it was for most of the British studios, and by 1937 Twickenham was in administration. Although he had hoped to started over again, his health and spirit failed and he died January 31, 1940.

With the assistance of the Foreign Office and Sir Robert Vansittart,its Permanent Under-secretary from 1930 to 1938, Herbert Wilcox's British and Dominion Films produced two distinctive films of empire: Victoria the Great (1936) and Sixty Glorious Years (1938), which were distributed by the British branch of RKO Radio Pictures. A disastrous fire at British and Dominion's Borehamwood Studios destroyed all three sound stages, and Wilcox later moved production to Pinewood. The Navy sponsored the production of Our Fighting Navy (1937), and the Army sponsored O.H.M.S (1938), both distributed through Gaumont. ${ }^{602}$ Thus it happened that both the War Office and the Foreign Office contributed in some small way to the popularisation of patriotic spirit and the realisation of Britain's need for a strong military, even as Hitchcock's films were warning of the rising danger from a resurgent Nazi Germany.

Malcom Muggeridge resurrects the British zeitgeist in The Thirties -

News films were popular; the March of Time series showed the world on a sheet of cloth; films like I Was a Nazi Spy made the Third Reich live in many a picture palace. Nothing was hidden, nothing secret under the sun." ${ }^{2}$

Although he gives us the impression generated by the drumbeat of anti-German films, Muggeridge has appar-

32 Malcolm Muggeridge, The Thirties - 1930-1940 in Great Britain, (London: Hamish Hamilton, 1940), 266. 
ently conflated the British film I was a Spy (Victor Saville, 1933) with the American Confessions of a Nazi Spy (Anatole Litvak, 1939). Still, there was much to worry about, and people wondered what would come next, whether revealed by the Universal Talking News or Lord Beaverbrook's Daily Express. The continuing release of propaganda films is correlated in the following table with important political events of the inter-war years.

Table Four: A Chronology of Events and Film Releases

01.30.1933 Hitler becomes Chancellor

02.09.1933 King and Country Debate

02.24.1933 Japan withdraws from League of Nations

02.27.1934 Reichstag Fire

04.01.1933 Jews banned from working in Film Industry

05.00.1933 Loyalties

07.00.1933 I Was A Spy

08.00.1933 Private Life of Henry VIII

10.31.1933 Germany withdraws from League of Nations

11.00.1933 The Wandering Jew

12.00.1933 On Secret Service

06.30.1934 Roehm purge

08.00.1934 I Spy

10.00.1934 Jew Süss

12.00.1934 The Man Who Knew Too Much

12.00.1934 The Iron Duke 


\author{
01.13.1935 Saar Plebiscite \\ 02.00.1935 Abdul the Damned \\ 04.00.1935 Sanders of the River \\ 05.00.1935 Brown On Resolution \\ 05.00.1935 Drake of England \\ 06.00.1935 The Thirty-Nine Steps \\ 07.00.1935 Me and Marlborough \\ 09.00.1935 The Passing of the Third Floor Back \\ 10.03.1935 Italy invades Ethiopia \\ 11.00.1935 Moscow Nights
}

01.20.1936 King George V dies

02.00.1936 Things To Come

03.07.1936 Germany occupies the Rhineland

03.00.1936 Rhodes of Africa

05.00.1936 Secret Agent

12.00.1936 Sabotage

12.10.1936 King Edward VIII abdicates

01.00.1937 Dark Journey

01.00.1937 O.H.M.S.

02.00.1937 Elephant Boy 
03.00.1937 Bulldog Drummond At Bay

04.00.1937 Our Fighting Navy

05.18.1937 King George VI is crowned

12.11.1937 Italy withdraws from League of Nations

03.12.1938 Germany invades Austria

04.00.1938 The Drum

08.00.1938 The Lady Vanishes

10.00.1938 Germany takes the Sudetenland

11.09.1938 Krystallnacht

02.00.1939 Q-Planes

03.00.1939 The Spy In Black

03.14.1939 Germany occupies Prague; Czechoslovakia dissolved

03.22.1939 Lithuania returns Memel to Germany

04.00.1939 The Four Feathers

04.07.1939 Italy invades Albania

06.00.1939 Four Just Men

09.01.1939 Germany invades Poland

11.09.1939 Venlo Incident 
Source: Rachel Low, Filmaking in 1930's Britain, (London: George Allen and Unwin, 1985),287-413. 


\section{Chapter Nine: Murder, Inc.}

Alexander Korda and his London Film Productions had became one of the major players in the quest to bring Britain to a realisation of the danger presented by Nazi Germany. Initially, it was Korda's purpose to emphasise loyalty to the Empire and the British social system. His friends at Gaumont British pursued a similar similar goal, though one which they approached from a somewhat different perspective. Because of the obstinacy of the British Board of Film Censors, they were obliged to approach anti-Semitism and the German military threat from a historical context. Thus Jew Süss was a success, but not Whither Germany?, or Brown on Resolution. Korda also explored this approach with Dark Journey and The Spy in Black. Echoing John Grierson's ideas, the major British film producers worked closely with the government to achieve a realisation of the danger which Nazi Germany presented, and to foster pride in English culture and nation.

W. E. B. Dubois" aphorism that "all art is propaganda" well applies to the films of Alfred Hitchcock, although he is not often thought to pursue political themes. In fact, selected examples of his work fall into three periods of political activism: The Cold War, encompassing North by Northwest, Topaz and Torn Curtain; World War II, - Foreign Correspondent, Saboteur, Lifeboat and Notorious, and his pre-war films The Man Who Knew Too Much, Sabotage, The 39 Steps and The Lady Vanishes. Sam Simone clearly identified Hitchcock's activist streak in Hitchcock as Activist - Politics and the War Films, although he gave short shrift to Hitchcock's earlier films,

His feature films, as ideological and historical documents, manifest the conflict between democracy and Nazism in the classical dramatic form of the conflict between protagonist and antagonist. Hitchcock's heroes and their associates are mainly protagonists who support democracy, while his villains and their associates are the antagonists who support Nazism. The dramatic forms of melodrama and suspense are the primary structural components of these films. They contain a definite propaganda level, well integrated yet discernible at the entertainment level. ${ }^{33}$

So also do Hitchcock's earlier films operate, but with restrictions brought about and placed on his work by the British Board of Censors. As a result, while his American films clearly name Germany and the National Socialist movement, his British films ere required to be more discreet, indicating an unnamed enemy and an unknown country. Rather than concentrating on the armed struggle, his British films are admonitory in nature: war had not yet been declared and their purpose was to alert and instruct the British people that danger existed.

Hitchcock's work was complementary to that of his two friends, Michael Balcon and Alexander Korda. Together, they produced an extended series of films with a two-fold purpose: to warn of the danger from Germany, and to encourage British rearmament. Beyond this, their agenda was supported and encouraged by Ml-6, in

33 Simone, xi. 
the person of Col. Dansey, who used his contacts to help establish London Films, and Alexander Korda's friend, Winston Churchill. As David Irving notes in Churchill's War

Fortunately a Hungarian film producer rescued him. A cigar smoking millionaire with a Homburg hat and an inch thick accent, Alexander Korda had just produced the first important British "talkie", The Private Lives of Henry VIII. ${ }^{34}$

Korda's support came at a propitious moment for Churchill, who struggled with financial problems through most of the decade. They became fast friends, and Churchill enjoyed Korda's support. His work with Col. Dansey especially provided intelligence on the increasingly threatening situation in Europe.

Churchill...lectured korda on how to make movies...Korda probably needed no lessons. He had arrived in England from Hollywood in 1930 and established London Films two years later...the film magnate shifted into Winston's social circle. The young Brendan Bracken later introduced him to Bernard Baruch as "one of Winston's great supporters when he was running his lonely battle to get Britain re-armed." when war broke out, Korda, who had become a British citizen, would move on to Hollywood and produce films flattering Britain's cause. ${ }^{35}$

Balcon produced three series of politically sensitive films: his Imperial films which antedated Korda's own Imperial films; Hitchcock's espionage thrillers, and a mixture of films, including Jew Süss, The Wandering Jew, and the Wilcox films, which Gaumont agreed to distribute, even after Balcon had left to head MGM Britain. When Balcon moved on to Ealing Studios, he produced a number of high quality war films, including The Foreman Went To France, San Demetrio London, and Went the Day Well?

Korda, on the other hand, worked much more closely with Churchill and MI-6, although he and Balcon often lunched together. Gaumont's The Man Who Knew too Much certainly, with its plot action derived from Churchill's own experiences, seems to show the hand of Korda, and perhaps Churchill as well.

How was this operation organised? Col. Dansey sat at the centre, like the arch-criminal Haghi in Fritz Lang's Spione. Through his friendships with influential bankers like Leopold Sutro and others, he secured financing for Korda's London films. When Korda needed more money, to build Denham Studios, Dansey and Churchill prevailed upon Sir Connop Guthrie of Prudential Assurance to invest in London Films, for the good of the nation. Korda, conferring with Churchill and Dansey, planned a programme of films to instil pride in British character, nation and achievement, and to warn against the growing danger of Nazi Germany.

From 1930, Dansey worked with Sir Robert Vansittart, Foreign Office Secretary and virulently anti-German. He has given his name to Vansittartism, a belief that the Germans must be soundly defeated militarily and con-

34 Irving p36

35 John Russell Taylor. Hitch: the Life and Work of Alfred Hitchcock. (Boston: Faber and Faber Ltd., 1978), 158. 
demned to one or two generations of retraining under United Nations auspices. Together, they established a new, secret intelligence corps using ordinary businessmen and travellers to obtain information on conditions in various countries, especially Germany. Their reports and observations were collected, collated through the Industrial Intelligence Centre, and distributed to the government and Churchill. Among Dansey's operatives at this time was William Stephenson, later known as "The Man called Intrepid" and the inspiration for lan Fleming's James Bond. By 1935, "Vansittart's Private Detective Agency” was moulded into the Z organisation - a secret intelligence network parallel to that maintained by the SIS itself. The Z Organisation, with the full knowledge and cooperation of Korda, who allowed his company to be used as cover, and actively assisted in its implementation, holding training courses in film and film production for Dansey's agents at Denham Studios.

Churchill seems to have enjoyed films, but preferred private screenings, which Korda helped arrange. Churchill's social milieu, as well as the membership of his support group "The Focus" (originally the British Non-Sectarian Anti-Nazi League) were elite peers and Members of Parliament. None of them could be remotely thought of as proletarian. Nor is there any strong link to the film industry, with the exception of Lady Violet Bonham-Carter, daughter of former Prime Minister Herbert Asquith, and sister to director Anthony Asquith. As a close friend and collaborator, Korda shared Churchill's ideas, and his work shows how he incorporated them in many of his films, along with similar sentiments from MI-6. Churchill and Korda exemplified the fin-de-sècle imperial tradition which animated and motivated Rudyard Kipling.

At Gaumont, Hitchcock had been thoroughly ---, letting on little of his actions or motivations. With the outbreak of the war, he remained tight lipped about his move to Hollywood. But even as he acceded to Churchill's suggestions, he came in for unfair criticism from people unaware of his informal labours for the government. As John Russell Taylor remarks on the unfortunate Hitchcock-Balcon contretemps,

Naturally, in all this flurry of accusation Hitch came in for his share. The most hurtful was from his old friend and associate Michael Balcon, who made an ill-considered statement to the press naming Hitch as one of those who had deserted Britain when she needed them most. Hitch and Alma were deeply upset that he of all people, who should have known better, had taken this line and her himself soon regretted it, since he was unofficially informed that Hitch...was continuing film-making in America at the express request of the British government. ${ }^{36}$

Donald Spoto, in The Dark Side of Alfred Hitchcock, amplifies this by describing the options open to Britain's most famous director:

36 John Russell Taylor. Hitch: the Life and Work of Alfred Hitchcock. (Boston: Faber and Faber Ltd., 1978), 158. 
In fact there was little Hitchcock could have done even if he had caught the first available flight back to London. He was ineligible for active military service, and any good he could do for the British cause was better done in America, where the film studios were still busy. In addition, Balcon was unaware, or chose to ignore, the open secret of Churchill's support of British filmmakers in America: Hollywood's product was one of the most effective weapons of propaganda in galvanizing America's sympathies toward England. ${ }^{37}$

Even so, Hitchcock returnned to England in December 1943, qand remained until the beginning of $M<$ arch, 1944, during which time he worked on two films for the Ministry of Information - Aventure Malgache and Bon Voyage, both French language films. While engaged on this project, he stayed at Claridge's Hotel in London, and spent much of his spare time visiting with Alexander Korda, who was also staying there. He also reconciled, perhaps with Korda's urging, with Michael Balcon. Sadly, Aventure Malgache was never issued in his lifetime (although Bon Voyage saw a very limited release in France), and the films remained mouldering in a vault until released fifty years later.

Is there concrete evidence in support of the existence of this informal collaboration? There is very little. In point of fact, it is sometimes the absence of evidence that seems most impressive and persuasive. Col. Dansey died, leaving no memoirs. This is unsurprising for two reasons - as an intelligence officers, he preferred, and was most effective, working behind the scenes. Further, an unfortunate incident when he was sixteen in which his mail was intercepted left him with a notorious lifelong aversion to setting anything down on paper. He had written a revealing note to an older boy, and his father was furious, ultimately exiling him to South Africa.

Korda also failed to leave an autobiography, and remained silent about his work with Dansey. Korda, was eventually to receive a knighthood through Churchill for war service, as mentioned in his nephew Michael's reminiscences Charmed Lives.

Hitchcock also left no written memoir, and was notably reticent about his private life. While his wife Alma was eager to gain American citizenship, Hitchcock himself did not become a citizen until 1954, suggestive of the sense of propriety and restraint befitting a British agent. The remaining three men involved did leave autobiographies, yet they are of little help. Sir Robert Vansittart, in The Mist Procession, admits that he had an informant in the German Air Ministry. Sir Michael Balcon, in Michael Balcon Presents. . .A Lifetime of Films largely speaks to his experiences within the film industry, giving us information on when he met Korda and Hitchcock, and alluding to meetings with Churchill, after the war started. Balcon was also knighted, by Churchill's successor Clement Atlee, probably for his work in producing propaganda films at Ealing Studios during

$\overline{37 \text { Spoto, p236 }}$ 
the war. He provides a great deal of background information, but only this curious afterthought on his time at the Lime Grove studios:

My final thought on this part of my life is one that has nagged at me for a long time. I realise that the preceding chapters of this personal story have been played against a shadowy background of world events - some world shattering. Alongside them, the then important seeming struggle and internal conflicts for the control of Gaumont British, ending with the disappearance of the Ostrer regime and the rise of the Rank empire, were relatively trivial. Those were, for example, the days of Mussolini's Abyssinian War,the Civil War in Spain, with all its implications for the future, and now that events can be seen in their historical perspective, one cannot escape the conclusion that in our own work we could have been more profitably engaged. Hardly a single film of the period reflects the agony of those times. ${ }^{38}$

But these wistful regrets fail to take into consideration the blocking effect of the British Board of Film Censors. Balcon dreams of actions that were simply not possible in those times. His comments, however, link his spirit to the activist undertakings of Hitchcock, and suggest perhaps, that the Ostrer brothers may have had some small rôle also.

The Osterer brothers came from a poor district in East London, and built an investment banking business. Isidore, the eldest, was a close friend of of Lord Beaverbrook, Churchill's confidant. He was known for his hands off approach, preferring to deal primarily with financial matters. Younger brother Mark has been previously mentioned in connection with the debut of Jew Süss. Another brother, Harry, worked with scripts and,as James C. Robertson notes in The British Board of Film Censors : Film Censorship in Britain, 1896-1950 a number of topical films about Germany and the mistreatment of herJews were proposed by Gaumont and killed at a by the board very early in their review process. Yet another brother (there were five in all), Maurice, acted, like Balcon, as an executive producer . His son, Nigel Ostrer, offered the opinion that "If the film industry changed public opinion, it was unintentional. They made films to entertain and make a profit," ${ }^{39}$ and while the latter half is probably correct, there has been sufficient research to suggest that changing public opinion was very far from being unintentional. It seems highly plausible, especially in view of their policy of hiring film professionals fleeing from the Nazis, which echoed the actions of Korda himself, that the brothers were aware of Balcon and Hitchcock's undertakings, and allowed them to continue with their tacit approval, if not their active involvement.

Winston Churchill wrote voluminously, but not always honestly. His multi-volume History of World War Il is marked by an elegant and intelligent style, but accuracy often fell victim to his primary goal of personal aggrandisement and mythmaking. He often twists or omits facts, especially if they would discredit him, or show him in a less favourable light. Revisionist historians have caught him leaving out material, or creating new 38 Balcon, 99.

39 E-mail dated February 25, 2010 Nigel Ostrer to Merle Peirce. 
stories, if they would add to his stature as master politician and statesmen.

It should also be remembered, in fairness to all participants, that discussion and description of their activities could well have been - by the Official Secrets Act which would bind them to silence. 


\section{Chapter Ten: After the Ball Was Over}

The men involved with the $\mathrm{Z}$ organisation toiled through the thirties to alert the British people to the approaching German danger, and to instil a willingness to rearm and oppose fascist autarchy. The work of Hitchcock in particular, brought awareness of Nazi dangers; Dansey and Korda were able to establish an independent espionage service, which survived the horrific coup of the German intelliegence services at Venlo. Balcon and Churchill were to render greater service during the war itself working, respectively, in propaganda films and command. Because of them, in the end, all England was ready for the inevitable. They listened to and accepted, with regret, the import of the Prime Minister's sad announcement broadcast by the BBC on September 3, 1939:

I am speaking to you from the Cabinet Room at Number 10 Downing Street. This morning the British Ambassador handed the German Government a note stating that unlessthey withdrew their troops from Poland by 11.00 a.m. a state of war exists between us. I have to tell you now, that no such undertaking has been received and, consequently, this country is at war with Germany. ${ }^{40}$

40 Humphrey Metzgen and John Graham, Caribbean Wars Untold: A Salute to the British West Indies (Kingston, Jamaica : University of West Indies Press, 2007), 105. 


\title{
Appendix A: British Prime Ministers 33
}

\author{
Herbert Asquith \\ 1908-1916 \\ David Lloyd George \\ 1916-1922 \\ Andrew Bonar Law \\ 1922-1923 \\ Stanley Baldwin \\ 1923-1924, 1924-1929, 1935-1937 \\ James Ramsay MacDonald \\ $1924,1929-1935$ \\ Neville Chamberlain \\ 1937-1940 \\ Winston Churchill \\ 1940-1945, 1951-1955 \\ Clement Attlee \\ 1945-1951
}

Source: Chris Cook and John Stevenson. The Longman Handbook of Modern British History 1714-1980. (London: Longman, 1985), 48-49. 


\section{Appendix B: Military Expenditures 1914-1946}

(in Millions of Pounds)

\begin{tabular}{|c|c|c|c|c|}
\hline & Army \& Ordinance & & Air Force & Votes of Credit \\
\hline 1914 & 28.3 & 48.8 & - & - \\
\hline 1915 & 28.9 & 51.6 & - & 357 \\
\hline 1916 & Note 1 & - & - & 1399.7 \\
\hline 1917 & Note 1 & - & - & 1973.7 \\
\hline 1918 & Note 1 & - & - & 2402.8 \\
\hline 1919 & Note 1 & - & - & 2198 \\
\hline 1920 & 395 & 156.5 & 52.5 & 87 \\
\hline 1921 & 181.5 & 88.4 & 22.3 & - \\
\hline 1922 & 95.1 & 80.8 & 13.6 & - \\
\hline 1923 & 45.4 & 56.2 & 9.4 & - \\
\hline 1924 & 43.6 & 52.6 & 9.6 & - \\
\hline 1925 & 44.8 & 55.6 & 14.3 & - \\
\hline 1926 & 44.3 & 59.7 & 15.5 & - \\
\hline 1927 & 43.6 & 57.6 & 15.5 & - \\
\hline 1928 & 44.2 & 58.1 & 15.2 & - \\
\hline 1929 & 40.5 & 56.9 & 16.1 & - \\
\hline 1930 & 40.5 & 55.8 & 16.8 & - \\
\hline 1931 & 40.5 & 52.6 & 17.8 & - \\
\hline 1932 & 38.5 & 51.1 & 17.7 & - \\
\hline 1933 & 35.9 & 50 & 17.1 & - \\
\hline 1934 & 37.6 & 53.5 & 16.8 & - \\
\hline 1935 & 39.7 & 56.6 & 17.6 & - \\
\hline 1936 & 44.6 & 64.8 & 27.5 & - \\
\hline 1937 & 54.8 & 81.1 & 50.1 & - \\
\hline 1938 & 63 & 78 & 56.3 & Note 2 \\
\hline 1939 & 85.7 & 95.9 & 72.8 & Note 2 \\
\hline 1940 & 81.9 & 69.4 & 66.6 & 408.5 \\
\hline 1941 & Note 1 & - & - & 3220 \\
\hline 1942 & Note 1 & - & - & 4085 \\
\hline 1943 & Note 1 & - & - & 4840 \\
\hline 1944 & Note 1 & - & - & 4950 \\
\hline 1945 & Note 1 & - & - & 5125 \\
\hline 1946 & Note 1 & - & & 4410 \\
\hline
\end{tabular}

Note 1 Military expenditures made from Votes of Credit.

Note 2 Exclusive of amounts released under Defense Loan Act 
Source: B. R. Mitchell, British Historical Statistics (Cambridge: Cambridge University Press, 1988), 591,594.

\section{Bibliography}

Andrew, Christopher. Her Majesty's Secret Service - The Making of the British Intelligence Community. New York: Viking Press, 1986.

Balcon, Michael. Michael Balcon Presents...A Lifteime of Films. London: Hutchinson \& Co., 1969.

Balcon, Michael, Hardy, Forsyth, Lindgren, Ernest, Manvell, Roger. Twenty Years of British Film 1925-1945. London: Falcon Press, 1947.

Cato [pseud.]. Guilty Men. London: Victor Gollancz, 1940.

Cave Brown, Anthony. C: The Secret Life of Sir Stewart Menzies, Spymaster to Winston Churchill. New York: Macmillan, 1987.

Chapman, James. Past and Present: National Identity and the British Historical Film. New York: I. B. Tauris, 2005.

Churchill, Winston S. While England Slept : A Survey of World Affairs, 1932-1938. New York: G.P. Putnam's Sons, 1938.

. The Unrelenting Struggle. comp. Charles Eade.Boston: Little, Brown, 1942.

History of the Second World War. Vol. 1, TheGathering Storm. Boston: Houghton Mifflin,

Curran, James and Vincent Porter, ed. British Cinema History. Totowa, New Jersey: Barnes and Noble, 1983. "British Imperial Cinema of the 1930's -Jeffrey Richards

Cook, Chris and John Stevenson. The Longman Handbook of Modern British History 1714-1980. London: Longman, 1985 ?.

Doerr, Paul W. British Foreign Policy 1919 - 1939: 'hope for the best, prepare for the worst'. Manchester: Manchester University Press, 1998.

Irving, David. Churchill's War Vol. I. Bullsbrook, Western Australia: Veritas Publishing, 1987.

Kennedy, John F. Why England Slept. New York: W. Funk, Inc., 1940.

Kitching, Carolyn J. Britain and the Problem of International Disarmament 1919-1934. London: Routledge, 1999.

Korda, Michael. Charmed Lives - A Family Romance. New York: Random House, 1979. 
Low, Rachael. History of the British Film 1929-1939: Film Making in 1930's Britain. London: Allen \& Unwin, 1985.

Lynch, Cecilia. Beyond Appeasement - Interpreting Interwar Peace Movements in World Politics. Ithaca: Cornell University Press, 1999.

Manchester, William. The Last Lion: Winston Spencer Churchill - Alone 1932-1940. Boston: Little Brown, 1988.

Marks, Sally. The Illusion of Peace. London: Macmillan Press, 1976.

Messimer, Dwight R. The Merchant U-boat. Annapolis, Md.: Naval Institute Press, 1988.

Metzgen, Humphrey and Graham, John. Caribbean Wars Untold : A Salute to the British West Indies. Kingston, Jamaica : University of West Indies Press, 2007.

Middlemas, Keith and John Barnes. Baldwin: A Biography. London: Weidenfeld and Nicolson, 1969.

Morris, Jan, ed. The Oxford Book of Oxford. London: Oxford University Press, 1978.

Nicholson, Colin. The Longman Companion to the First World War. New York: Pearson Longman, 2001.

Read, Anthony and Fisher, David. Colonel Z:The Secret Life of a Master of Spies. New York: Viking, 1984.

Richards, Jeffrey. The Age of the Dream Palace: Cinema and Society in Britain 1930-1939. London: Routledge, 1984.

. The Unknown 1930's. London: I. B. Tauris, 1998.

Visions of Yesterday. London: Routledge and Kegan Paul, 1973.

Robertson, James C. The British Board of Film Censors : Film Censorship in Britain, 1896-1950 . Dover, NH: Croom Helm, 1985.

. Hidden Cinema: British Film Censorship 1913-1975. London: Routledge, 1993.

Simone, Sam P. Hitchcock as Activist - Politics and the War Films. Ann Arbor: UMI Research Press, 1985.

Spoto, Donald. The Art of Alfred Hitchcock. $2^{\text {nd }}$ ed. New York: Doubleday, 1992.

The Dark Side of Genius - The Life of Alfred Hitchcock. Boston: Little, Brown, 1983.

Stewart, Graham. Burying Caesar: The Churchill-Chamberlain Rivalry. Woodstock, NY: Overlook Press, 1999.

Stevenson, William. A Man Called Intrepid: The Secret War. New York: Lyons Press, 2000.

Taylor,John Russell. Hitch: the Life and Work of Alfred Hitchcock. Boston: $\quad$ Farrar and Farrar, Ltd., 1978. 
Truffault, François. Hitchcock. New York: Simon and Schuster, 1985.

U.S. Department of State. Foreign Relations of the United States: 1922, Vol. 1, (Washington, DC: GPO, 1936). CONFERENCE ON THE LIMITATION OF ARMAMENT p247-266

Vansittart, Lord. The Mist Procession. London: Hutchinson, 1958.

Waller, John H. The Unseen War in Europe : Espionage and Conspiracy in the Second World War. London : I.B. Tauris, 1996.

Welch, David. Propaganda and the German Cinema: 1933 - 1945. London: I. B. Tauris, 2001.

Yacowar, Maurice. Hitchcock's British Films. Hamden, Connecticut: Archon, 1977. 


\section{Filmography}

Dark Journey, Victor Saville dir., London Film Productions, 1937.

I was a Spy, Victor Saville, dir., Gaumont British, 1933.

Jew Süss, Lothar Mendes dir., Gaumont British, 1934.

Q-Planes, Tim Whelan and Arthur B. Woods, Irving Asher Productions, 1939.

Sabotage, Alfred Hitchcock dir. Gaumont British, 1936.

Sanders of the River, Zoltan Korda dir., London Film Productions, 1935.

Secret Agent, Alfred Hitchcock dir., Gaumont British, 1936.

The Drum, Zoltan Korda dir., Alexander Korda Films, 1938.

The Four Feathers, Zoltan Korda dir., London Film Productions, 1939.

The Lady Vanishes, Alfred Hitchcock dir., Gainsborough Pictures, 1938)

The Lion Has Wings, Adrian Brunel, Brian Desmond Hurst, Michael Powell, Alexander Korda (uncredited) dir., London film Productions, 1939.

The Passing of the Third Floor Back, Berthold Viertel dir., Gaumont British,1935.

The Private Life of Henry the VIII, Alexander Korda dir., London Film Productions, 1933.

The Spy in Black, Michael Powell dir., Irving Asher Productions, 1939.

The Wandering Jew , Maurice Elvey dir., Gaumont British/Twickenham Studios, 1933.

Things to Come, William Cameron Menzies dir., London Film Productions, 1936. 

